\title{
A síntese imperfeita: articulação entre política externa e política de defesa na era Cardoso
}

\author{
JOÃO PAULO SOARES ALSINA JR.*
}

\section{Introdução}

O presente artigo tem por fundamento a dissertação de mestrado defendida pelo autor, em dezembro de 2002, junto ao Departamento de Relações Internacionais da Universidade de Brasília (UnB). O título do trabalho apresentado à UnB, “A síntese imperfeita: articulação entre política externa e política de defesa na Era Cardoso (1995-2002)”, pretendeu dar conta de uma questão central: como se processaria a articulação entre a política externa e a política de defesa durante a gestão de Fernando Henrique Cardoso (FHC) a partir da análise de dois episódios específicos e inter-relacionados - a formulação da Política de Defesa Nacional (PDN), em 1996, e a criação do Ministério da Defesa (MD), em 1999. Por corresponder ao que de mais significativo ocorreu em termos de modificações do arcabouço institucional relacionado ao setor de defesa e por suas claras implicações para a interface diplomacia-forças armadas, optou-se por realizar um estudo de caso sobre o processo de delineamento da PDN e de suas repercussões para a posterior implantação do MD. Em vista das limitações de espaço, este artigo abordará de maneira muito pontual a inter-relação entre a publicação da PDN e a constituição do MD.

Ainda que os processos de formulação da PDN e do MD tenham ambos contado com a participação de diplomatas e militares, faz-se necessário um esclarecimento: a publicação da PDN e a criação do MD representaram acontecimentos interligados. Contudo, mesmo que se suponha que uma política necessite de um agente capaz de implementá-la, há uma distinção entre os exercícios que deram origem à primeira e ao último no que tange à articulação entre política externa e de defesa. Enquanto a PDN implicava necessariamente uma avaliação do quadro político-estratégico internacional à luz dos objetivos de política externa brasileiros, o MD suscitava o estabelecimento de novas formas de coordenação (diálogo unificado) entre o Itamaraty e as forças singulares. 
Embora tanto um quanto o outro constituam exemplos de processos em que algum tipo de interação entre as duas políticas teria forçosamente que se processar, não se pôde abordar os dois de forma idêntica. Prioridade foi atribuída à análise da PDN em face de sua natureza, uma vez que se pretendeu determinar os padrões de articulação existentes a partir do ponto de vista da instrumentalidade da política de defesa para a política externa.

\section{Algumas palavras sobre conceitos}

Conceitos all-encompassing como os de segurança, poder, democracia etc., são extremamente difíceis de abordar em função de sua infinita complexidade. Esse fato, no entanto, não pode desestimular o analista. Acredita-se, portanto, que uma das mais importantes contribuições recentes à discussão sobre segurança tenha sido dada por Barry Buzan et al. ${ }^{1}$ Os mencionados autores procuraram elaborar uma moldura conceitual capaz de romper com a dicotomia existente, na literatura anglo-saxã, entre os Traditional Security Studies (TSS) e os Critical Security Studies (CSS). Fundamentalmente, argumentam que não é possível determinar de maneira objetiva o que seria uma ameaça a um objeto referente da segurança - seja ele um indivíduo, um Estado ou qualquer outro. Adotando uma posição radicalmente construtivista, supõem que a percepção de ameaça ocorre por meio da relação intersubjetiva entre atores “securitizadores” e o público-alvo do ato de fala que enuncia a tentativa de securitização (essa, uma vez efetivada, corresponderia à elevação, acima dos constrangimentos procedimentais inerentes ao tratamento político de um problema coletivo em poliarquias institucionalizadas, das ações adotadas para debelar a ameaça à existência de um determinado objeto referente da segurança). Ademais, Buzan et al. estendem a abrangência da aplicação do conceito de segurança para além do tradicional domínio militar, incorporando também os setores econômico, político, ecológico e societal.

A partir das ferramentas conceituais fornecidas pela definição acima citada, torna-se necessário dar um passo adicional e imprescindível: se se aceita que os processos de securitização são intersubjetivamente determinados - não havendo metodologias eficazes para a determinação objetiva de ameaças a objetos referentes da segurança, qual é o limiar que permite estabelecer a distinção entre um processo de securitização bem sucedido e outro que se encontra em vias de se concretizar - e que talvez não venha a sê-lo? O aparato conceitual mencionado não dá conta satisfatória desse problema. Permanece a questão sobre onde se deve estabelecer a cut-off line para a separação daquilo que é securitizado daquilo que não é. No caso brasileiro, a aplicação da idéia de securitização tal como formulada por Buzan et al., a despeito de suas deficiências, tem a vantagem de livrar o estudioso da camisa de força representada pela perspectiva objetivista e funcionalista da Escola Superior de Guerra (ESG) sobre segurança. Nessa linha, 
considera-se que é possível analisar a problemática de defesa no Brasil a partir do arcabouço conceitual delineado por Barry Buzan e seus colaboradores.

Ora, se as ameaças à segurança podem ser encaradas como um construto cujo conteúdo será determinado por meio de processos de securitização específicos, como considerar o conceito de defesa? Seguindo a posição aqui adotada, deduzse logicamente que a defesa não é senão um dos setores em que a segurança pode ser subdividida para fins analíticos. Assim, a defesa é o que se poderia denominar de segurança militar externa, pois não se pode negar o fato de que as forças armadas, na condição de burocracias especializadas na utilização racionalizada dos meios de coerção, possuem, na maior parte dos países, e também no Brasil, funções concernentes à segurança interna - manutenção da lei e da ordem, por exemplo. Em conseqüência, uma política de defesa deve ser encarada como uma política pública responsável por regular não somente a estruturação das forças armadas como instrumentos do poder político nacional, mas, sobretudo, garantir que o poder militar gerado por estas estruturas (Marinha, Exército e Aeronáutica) seja capaz de equilibrar as relações de força existentes entre os Estados no plano internacional. Decorre desse fato primordial a conexão entre a política externa e a política de defesa.

\section{O mundo, a América do Sul e o Brasil: os limites das políticas externa e de defesa da era Cardoso}

É possível estabelecer três linhas de força da política externa ao longo dos anos 1990: a afirmação da dinâmica democrática brasileira e de seus desdobramentos no plano internacional (e vice-versa, ou seja, a influência do contexto externo sobre o processo político local); a tentativa de inserção competitiva do Brasil na economia mundial por meio da assimilação da lógica do livre mercado como elemento propulsor do desenvolvimento nacional; e a reiteração da compatibilidade entre os valores esposados pelos brasileiros e os pressupostos de uma ética cosmopolita relacionada ao respeito aos direitos humanos, à preservação do meio ambiente, o combate ao crime transnacional, entre outros. Poder-se-iam resumir as três linhas mencionadas em conceitos-síntese, que seriam os seguintes: Democracia, Mercado e Direitos Humanos (a divisão mencionada justifica-se na medida em que se possui como objetivo representar as esferas política, econômica e valorativa respectivamente). É evidente que esses conceitos, por sua generalidade, não explicam nem abarcam todas as dimensões da política externa. São úteis, contudo, para delinear o sentido geral das políticas adotadas.

Com maior ou menor ênfase em alguma das dimensões expressas pelos conceitos-síntese, modulações aqui ou acolá, a política externa brasileira não sofre rupturas significativas ao longo do período que se inicia com a presidência de Fernando Collor e estende-se à gestão de Fernando Henrique Cardoso. A 
inexistência de rupturas importantes não elide o fato de que houve modulações ao longo dos três governos cujos mandatos correspondem à década de 1990 e ao início da primeira década do século XXI. Nesse sentido, acredita-se ser possível apontar uma leve inflexão do discurso diplomático brasileiro dentro da própria presidência FHC, ainda que não admitida ou alardeada. Pode-se dividir a gestão FHC em dois períodos no que se refere à política externa. Esses corresponderiam, grosso modo, aos dois mandatos presidenciais: 1995-1999 e 1999-2002. A hipótese aqui formulada é de que houve uma mudança na percepção do caráter do processo de globalização, sobretudo a partir do fracasso da Conferência Ministerial da Organização Mundial do Comércio, em Seattle. Desse momento em diante, a diplomacia brasileira passa a ter uma posição mais assertiva no tocante à crítica do modelo vigente de estruturação da economia internacional. A percepção da injustiça representada pelas normas da OMC, tendencialmente favorável às nações ricas, e pelo protecionismo dos países centrais, especialmente no que se refere ao mercado de produtos agrícolas, teria motivado o início da inflexão mencionada.

Não foi somente a impossibilidade de se lançar uma nova rodada de liberalização comercial em Seattle que motivou a inflexão do discurso. Contribuiu para isso toda a série de crises financeiras pelas quais passaram os países “emergentes” a partir de 1997. A crise da Tailândia, seguida das crises da Ásia, da Rússia e, finalmente, do Brasil, em 1998/1999, demonstraram a fragilidade dessas economias diante dos efeitos potencialmente explosivos do capital financeiro internacional. Pode-se supor, ainda, que, no plano político, o crescente esvaziamento da Organização das Nações Unidas (ONU) patrocinado pelos norte-americanos (ou a substituição das ações concertadas no âmbito do Conselho de Segurança das Nações Unidas (CSNU) pelo consentimento plurilateral restrito da Organização do Tratado do Atlântico Norte (OTAN) - no caso do conflito da Bósnia), a nãoratificação pelo senado dos Estados Unidos do CTBT (Tratado para o Banimento Total de Testes Nucleares), a acomodação, pelas grandes potências, das explosões de artefatos nucleares por parte de Índia e Paquistão, entre outros eventos, teriam introduzido uma nota de cautela em relação à possibilidade de que estivesse havendo uma modificação estrutural do sistema internacional tão profunda a ponto de diminuir as clivagens e as assimetrias existentes entre os have e have nots. Finalmente, a modulação de discurso percebida na transição do primeiro para o segundo mandato também pode ter sido influenciada pelo fato de que Cardoso não poderia mais ser reeleito. Tratava-se, nessa linha, de incorporar discretamente críticas da oposição no discurso da política externa como forma de anular, pela absorção, a validade da retórica oposicionista - sobretudo aquela propalada pela esquerda.

É em contextos doméstico e internacional complexos, em que o nível de incerteza se sobrepõe claramente ao já conhecido e mapeado, que transitará a política externa de Fernando Henrique Cardoso. Apesar disso, cabe mencionar 
que, em poucas ocasiões na história republicana, um Presidente possuiu tantas credenciais para o exercício efetivo de formulação da política externa. Embora Sérgio Danese mencione o fato de que foi o Itamaraty o responsável pela elaboração do conceito de diplomacia presidencial, não há dúvida de que o perfil do primeiro mandatário foi determinante para que se pudesse deslanchar um intenso programa de visitas ao exterior a partir de sua posse. ${ }^{2}$ Os objetivos centrais da mencionada iniciativa eram os de garantir uma adequada avaliação do Brasil, a partir do advento do Plano Real, por parte de seus principais parceiros - sobretudo com base na necessidade de atração de investimentos e capitais - bem como o de elevar o nível de interlocução do País com as lideranças das nações visitadas. Em suma, a partir de 1995, o Brasil passou a contar com um primeiro mandatário claramente consciente da importância da política externa para seu projeto de governo e interessado em traçá-la pessoalmente.

\section{Democracia, Mercado, Direitos Humanos}

O conceito de democracia expresso de forma incisiva no discurso da diplomacia brasileira ao longo da gestão Cardoso não se confunde com qualquer concepção teórica específica. Dessa forma, deve-se procurar definir o escopo de sua utilização no plano declaratório da política externa. Em primeiro lugar, é preciso admitir que o grau de generalidade com que foi utilizado dá margem a inúmeras interpretações. Análise mais detida parece indicar, contudo, que o conceito de democracia, tal como foi enunciado, possuía dupla função: descrever uma realidade doméstica e enfatizar a compatibilidade entre essa realidade e os standards de organização política prevalecentes nos países desenvolvidos do Ocidente. A reiteração da democracia teve como fulcro as idéias de valores compartilhados e de afirmação da identidade existente entre o Brasil e os membros do mundo democrático. Apesar da retórica prudente, característica da diplomacia brasileira ${ }^{3}$, acreditava-se cautelosamente que o processo histórico em marcha apontava para a transformação qualitativa do mundo. Supunha-se que essa permitiria aos países em desenvolvimento maior participação nos diversos tabuleiros onde se desenrolavam as relações internacionais.

Seria incorreto, apesar do acima exposto, alegar que os formuladores da política externa teriam se deixado seduzir, ingenuamente, pela esperança de uma nova ordem mundial estável, livre de assimetrias de poder e mais favorável aos países de menor peso relativo. A ênfase do discurso diplomático de Cardoso na possibilidade de um sistema internacional mais democrático possuía, portanto, importante conteúdo retórico (tático). Tratava-se, assim, de reforçar um conceito difuso de democracia como a causa/conseqüência de um mundo tendente à diminuição dos desequilíbrios que historicamente o caracterizaram. O Brasil, como país onde a liberdade política se consolidara, teria uma contribuição a dar nesse 
sentido, incrementando seu capital de legitimidade ao defender o vínculo entre a democracia e um processo decisório menos concentrado no plano internacional.

Se a tradição de prudência e realismo da política externa brasileira não permitiu que se adotasse uma perspectiva transformacionista do mundo ${ }^{4}$, pode-se observar, contudo, uma tendência muito forte, no primeiro mandato de Cardoso, a retratar a processo de globalização como algo inevitável, irreversível, que impunha enormes restrições à capacidade de atuação do Estado. Nessa linha, é preciso enfatizar a existência de flutuações, até mesmo de certa ambigüidade, no que se refere à avaliação da margem de manobra do País no contexto de um mundo cada vez mais complexo. Embora o Presidente tenha criticado, em diversas ocasiões, a ausência de regras que permitissem aos Estados nacionais controlar, por exemplo, os efeitos potencialmente devastadores dos fluxos internacionais de capitais, parece lícito argumentar pela existência, em seu primeiro mandato, de um alto grau de cautela em relação ao aumento do perfil da crítica aos efeitos perversos da globalização. Partia-se da constatação de que os novos meios de transporte e comunicação mudaram a lógica de organização produtiva, o que permitia a dispersão das cadeias de manufaturas por vários pontos do planeta onde houvesse um ambiente amigável ao investimento. Avaliava-se, igualmente, que, ao menos no horizonte previsível, a preponderância (ou mesmo hegemonia) americana constituiria fator estruturador do sistema internacional, assim como a força homogeneizadora dos valores exportados pelos Estados Unidos: democracia, livre mercado, direitos humanos. Esses valores seriam crescentemente aceitos e adotados em escala global, restando aos recalcitrantes a marginalidade.

Gélson Fonseca Jr., por exemplo, avaliava como correta a idéia de que o mais convincente quadro explicativo das relações internacionais do período em tela seria aquele que identificava a existência de um sistema de concerto entre as grandes potências. Ao contrário do concerto europeu do século XIX, composto por um grupo de países com recursos de poder semelhantes, o atual singularizarse-ia pela gravitação de várias potências secundárias em torno dos Estados Unidos. ${ }^{5}$ A preponderância de valores compartilhados e a inexistência de divergências fundamentais entre os principais atores fariam com que o concerto permitisse uma melhor administração da ordem mundial ao estabelecer regimes universais capazes de dar conta das questões que, por seu caráter sistêmico, não poderiam ser adequadamente resolvidas por nenhum país isoladamente. Resulta evidente a pergunta: se se está falando em um sistema de concerto, como ocorreria no plano concreto a formulação dos regimes e qual o seu sentido? Na linha do que parece ser a percepção dominante da diplomacia de Cardoso, durante seu primeiro mandato, acreditava-se na possibilidade de que a formulação dos regimes internacionais fosse franqueada a um maior número de países e de que seu sentido seria o da inclusão (da “democratização”), uma vez que a legitimidade estaria condicionada ao multilateralismo. 
O desdobramento lógico dessa avaliação era a necessidade de adequação do País ao mainstream internacional (aos regimes das mais diversas naturezas, em especial) como requisito essencial para participar do jogo. Percebe-se que os custos da não-adequação seriam altos demais e que prejudicariam a pretensão brasileira de ver aumentado o seu espaço de proposição nos debates que levavam à construção da ordem internacional. A exaltação dos valores democráticos aparece nesse quadrante alinhada ao rumo supostamente escolhido pela sociedade brasileira quanto a seu sistema político e inserção externa. Além da percepção sobre as tendências prevalecentes no plano mundial, a avaliação dos atributos domésticos contribuiu decisivamente para a conformação da política externa de Cardoso. Um dos principais fatores que determinaram o impulso em direção à busca de "autonomia pela participação" foi a constatação de que o País não mais teria condições de arcar com os custos de transgressão dos regimes e tampouco capacidade de aspirar à construção da potência. ${ }^{6}$

Tratava-se, então, de priorizar a economia em detrimento da política. E foi exatamente isso que aconteceu, sobretudo, na primeira gestão Cardoso. A integração regional, traduzida pelo projeto do Mercosul, tornar-se-ia, nas palavras de um analista, o alfa e o ômega da política externa brasileira. ${ }^{7}$ Nessa linha, clara foi a tendência à adoção de uma não-explicitada identidade entre concessões no plano político internacional e supostos benefícios na esfera econômica. Ora, não é possível identificar, por exemplo, onde a alegada transferência de tecnologia decorrente da adesão brasileira a, praticamente, todos os regimes internacionais de não-proliferação teria se processado. Da mesma forma, difícil é admitir como a simples reiteração da relativa identidade de valores do Brasil, na condição de membro de um "outro Ocidente", com o eixo euro-atlântico fosse capaz de minimizar as acentuadas discrepâncias de interesses relacionados à posição estrutural ocupada por países desenvolvidos e em desenvolvimento na divisão internacional do trabalho e do poder.

Finalmente, supõe-se aqui que a já mencionada modulação percebida no plano declaratório da política externa brasileira, no segundo mandato de Cardoso, não tem correspondência em uma mudança de rumo acentuada no plano empírico. A fragilidade do Brasil no campo econômico, a permanência da agenda negativa na área social, a elevação dos temas de segurança à condição de prioridade internacional número um impulsionada pelos Estados Unidos, entre outros fatores, tornaram mais difícil traduzir em ações efetivas a postura internacional mais crítica assumida pelo País a partir de 1999.

\section{A dimensão da segurança internacional}

No que se refere ao sistema internacional de segurança, uma série de fenômenos inter-relacionados se produziram ao longo da era Cardoso: o 
fortalecimento simultâneo da globalização e da regionalização dos arranjos de segurança coletiva, a aceleração do avanço tecnológico verificado no setor de armamentos - com o decorrente aumento do hiato tecnológico entre os países desenvolvidos (os Estados Unidos, em especial) e os países em desenvolvimento - bem como o fortalecimento dos regimes de não-proliferação de armas de destruição em massa. ${ }^{8}$ Alguns analistas chegaram a formular a tese de que, cada vez mais, consolidava-se o que qualificaram como uma "bifurcação estrutural" no mundo. ${ }^{9}$ De um lado, o norte próspero e democrático, vivendo em uma comunidade de segurança pluralista (onde o recurso à guerra seria impensável entre seus membros), e o sul pobre e violento, onde a guerra seria recorrente e disseminada. Os Estados Unidos exerceriam sua hegemonia incontestável no plano militar e escolheriam, à sua discrição, intervir onde quer que fosse de acordo com o interesse nacional norte-americano.

No plano regional, a predominância da democracia em todo o subcontinente sul-americano, os processos de aproximação comercial, a identidade de valores (incluindo a tradição jurisdicista da região), a sombra da superpotência no hemisfério, a baixa capacidade de projeção de poder (mesmo do Brasil), entre outros fatores, reforçariam a tese de que a América do Sul constituiria uma zona de paz ou, ao menos, uma zona sem guerras. ${ }^{10}$ No plano doméstico, a severa crise fiscal do Estado, a ausência de percepções de ameaça externa clássica (estatal), a prioridade atribuída a programas sociais, a generalizada falta de conhecimento sobre a instrumentalidade do poder militar e o desinteresse do poder político por assuntos castrenses contribuíram para o baixo perfil adotado pela gestão FHC no setor de defesa. A baixa prioridade atribuída ao setor se viu reforçada, igualmente, pela percepção dominante no seio dos formuladores da política externa brasileira. À tradição de cautela, jurisdicismo e não-intervencionismo da diplomacia local, somou-se a noção de que as relações de força no plano internacional seriam cada vez mais limitadas em conseqüência, basicamente, da convergência de valores, da expansão do comércio e da crescente dificuldade de legitimação do recurso à guerra junto à opinião pública mundial.

\section{A formulação da PDN}

Ainda na campanha eleitoral de 1994, FHC expressara sua intenção de criar no Brasil um Ministério da Defesa (MD) que incorporasse a Marinha, o Exército, a Aeronáutica e o Estado-Maior das Forças Armadas (Emfa). ${ }^{11}$ Não há dúvida de que o supremo mandatário conhecia as resistências castrenses à interposição de um escalão hierárquico entre as forças singulares e ele. Essa resistência, aliás, não era nova e podia ser traçada nas discussões que deram origem à Constituição de 1946 - quando alguns legisladores brasileiros cogitaram a hipótese de criação do MD. ${ }^{12}$ Para além da frustrada tentativa de Castelo Branco 
visando à reformulação da estrutura de defesa brasileira no âmbito do Decreto-lei 200, no passado mais recente, aproveitando o capital político derivado de uma transição pactuada, os militares se oporiam tenazmente à idéia do MD aventada por parlamentares durante a Assembléia Nacional Constituinte (ANC). ${ }^{13}$

Ao convidar os oficiais-generais que ocupariam os cargos de Ministros da Marinha (almirante Mauro César Pereira), do Exército (general Zenildo Zoroastro de Lucena), da Aeronáutica (brigadeiro Mauro Gandra) e do Emfa (general Benedito Bezerra Leonel) - esse último novamente elevado à categoria de ministério, FHC deixou clara sua intenção de criar o MD. ${ }^{14}$ Aqui cabe uma nota de esclarecimento: o general Leonel ressaltará o sentido do termo intenção, que seria bastante diferente de decisão. ${ }^{15}$ Essa diferenciação não se reduz, evidentemente, a uma sutileza semântica. Ao enfatizar a palavra intenção, o Ministro-Chefe do Emfa introduz um elemento de condicionalidade no processo que redundaria na criação do MD. Logo, à medida que afirmava sua intenção, o Comandante-em-Chefe estaria deixando espaço aberto para a negociação e, em conseqüência, para a assimilação gradual da idéia pelo estamento militar. Não se trataria, portanto, de uma imposição a partir de decisão previamente tomada, mas de uma paulatina construção de consenso que poderia, em última instância, não resultar no MD. A corroborar a interpretação do referido oficial-general, está a ausência de menção ao novo ministério no discurso de posse do supremo mandatário.

Independentemente dessa qualificação, todos os oficiais que viriam a assumir os ministérios militares, além do diplomata apontado para a chefia do Itamaraty, são unânimes em admitir que FHC tratou do tema quando do convite para a assunção de suas respectivas pastas. ${ }^{16}$ Se parece difícil supor, como decorre do depoimento do general Leonel, a possibilidade de não-constituição do MD contrariamente à intenção do Presidente, é forçoso constatar que todo o processo foi marcado pelo gradualismo e pelo comedimento. Tratava-se de deixar a idéia “decantar”, tornando-a digerível pela caserna. Nessa linha, vale registrar a afirmação do Ministro-Chefe do Emfa de que, em suas conversas com o supremo mandatário, teria ponderado que pelo menos 70\% dos oficiais do Exército seriam contrários à criação do MD, mas que a vasta maioria deles possuiria informação insuficiente para formar uma opinião fundamentada. ${ }^{17}$ Difundida entre o oficialato era a suposição de que a iniciativa presidencial seria fruto de pressões internacionais, provenientes especialmente dos Estados Unidos - país cuja política externa teria como objetivo transformar as Forças Armadas latino-americanas em unidades de combate ao narcotráfico.

Logo, ao aceitar a diretiva do Comandante-em-Chefe, o general Benedito Leonel estava convencido de que, com tempo e esforço de convencimento, as resistências corporativas poderiam ser quebradas. Afinal, os conflitos bélicos contemporâneos haviam demonstrado que a capacidade de atuação combinada das forças era cada vez mais um elemento decisivo para o sucesso na guerra. $\mathrm{O}$ 
MD poderia representar, assim, avanço no sentido de maior integração entre Marinha, Exército e Aeronáutica - sobretudo no campo da logística. ${ }^{18}$ Nessa linha, é preciso assinalar que ao Emfa, em vista de seu papel de coordenação, caberia a tarefa de formar o núcleo a partir do qual seria constituído o futuro Ministério da Defesa. As resistências detectadas no Exército não eram isoladas. A Marinha, em especial, via com enorme reticência a possibilidade de constituição do Ministério da Defesa. Da mesma forma, a Aeronáutica não era inicialmente simpática à idéia. Os estudos iniciados pelo Emfa, com a finalidade de recolher subsídios para a análise dos modelos de estruturação dos MDs existentes no mundo, foram conduzidos sem açodamento. Ocorre que em face das informações acumuladas pelo Estado-Maior das Forças Armadas, resultantes dos estudos iniciais denominados "exploratórios", tornava-se gritante a singularidade da estrutura administrativa nacional relacionada à defesa: entre 179 países pesquisados, somente 23 não possuíam MDs, sendo que a maior parte era formada por nações pouco expressivas (ilhas, arquipélagos, países minúsculos etc.). Entre os Estados mais importantes, apenas Japão, México e Brasil mantinham o formato de dispersão dos temas militares em vários ministérios. ${ }^{19}$

Cabe assinalar um outro aspecto importante dos trabalhos que visavam ao recolhimento das informações que embasariam a modelagem institucional do futuro ministério. Esse era o do virtual monopólio exercido pelo estamento militar sobre sua condução. Coube exclusivamente ao Emfa coordenar os estudos exploratórios e estabelecer os princípios que fundamentariam a seleção dos dados obtidos. Esses últimos seriam, sucintamente: a não-importação de modelos alienígenas, a mudança com moderação, a não-confrontação da tradição militar brasileira e a rejeição de artificialismos. ${ }^{20}$ Diante do que precede, a sinalização emitida pelo Presidente ao encarregar o general Leonel da tarefa, para além do objetivo de evitar melindres, indica a baixa prioridade atribuída aos aspectos administrativos daquilo que viria a ser o MD. Embora a idéia de avançar gradualmente e de forma segura fosse um valor fundamental a permear o processo, no momento em que FHC deixa nas mãos dos próprios militares a construção institucional do pretendido ministério, não estaria ele permitindo que fosse adotada uma estratégia a la Lampedusa por parte da caserna?

Assim, a determinação presidencial de reconfigurar o formato institucional do tratamento das questões de defesa no Brasil parece ter obedecido a uma lógica complementar. Se, por um lado, tratava-se de avançar no caminho da submissão das Forças Armadas ao poder civil, por outro, pretendia-se dotar o País de um arcabouço mais moderno para o encaminhamento da problemática em tela, compatível com o padrão identificado na grande maioria das nações democráticas. ${ }^{21}$ Embora seja temerário sustentar que o argumento da modernização e da racionalização do sistema de defesa tenha sido determinante para a ação governamental (até porque, conforme o anteriormente aludido, estava nas mãos 
das próprias forças dar feição ao MD), não se pode deixar de considerar a sua relevância. Como o governo FHC levava a cabo um programa de reforma do Estado, é difícil assumir que o setor militar permanecesse completamente alheio a esse contexto. Nessa linha, ao se buscar a afirmação de uma nova sistemática de planejamento, traduzida no Plano Plurianual (PPA) 1996/1999, criou-se um Comitê de Assuntos de Defesa. ${ }^{22}$ Em um primeiro momento, contudo, o Ministério do Planejamento e Orçamento (MPO) não previa a existência do citado Comitê. Esse foi criado posteriormente em função de pedido encaminhado pela SAE - em face de solicitação das forças singulares. O Comitê em questão, que reunia militares, diplomatas, acadêmicos e técnicos das áreas de orçamento e planejamento, foi inovador por ter possibilitado o diálogo e o intercâmbio de visões sobre a temática da defesa nacional entre civis e representantes da caserna. A partir de uma definição genérica do quadro internacional, procurou-se estabelecer um elenco de prioridades - em termos de programas e de aquisição de sistemas de armas - e as dotações orçamentárias correspondentes. Para tanto, os membros do Comitê decidiram aproveitar como subsídio o documento "Bases para uma Política de Defesa”, elaborado pela Secretaria de Assuntos Estratégicos (SAE) em 1994.

Em entrevista ao autor, o general Benedito Leonel admitiu que somente no segundo semestre de 1996 os estudos exploratórios foram finalizados e apresentados aos ministros militares. Até essa data, “não se fez nada” em termos de coordenação das posições das forças singulares a respeito do formato projetado para o Ministério da Defesa. ${ }^{23}$ Havia uma espécie de resistência passiva à determinação presidencial: Marinha, Exército e Aeronáutica permaneciam em silêncio, esperando para ver o que iria acontecer. A contribuir para a paralisia, pode-se citar, entre outros motivos, a suspeita das forças singulares de que o Ministro-Chefe do Emfa estaria trabalhando nos bastidores por sua nomeação para o futuro cargo de Ministro da Defesa. ${ }^{24} \mathrm{~A}$ apresentação dos estudos exploratórios, contudo, ensejou a constituição de um Conselho de Vice-Chefes de Estado-Maior (Convice) - reunindo as três forças e coordenado pelo Emfa - cuja tarefa era formular uma posição comum sobre o assunto. Embora inesperado, não é de causar espanto o fato de que o referido Conselho tenha elaborado trabalho em que a principal conclusão é a da inconveniência de se criar o MD. ${ }^{25}$

Não poderia ser mais explícita a enumeração dos motivos pelos quais as Forças Armadas rejeitavam a criação do MD. O referido estudo mencionava também que, caso houvesse a necessidade inevitável de estabelecimento do MD, esse deveria suceder o Emfa a médio ou longo prazo, sem que se procedesse necessariamente à extinção dos demais ministérios militares. ${ }^{26}$ Essa posição seria depois publicamente defendida pela Marinha. Há, contudo, uma discrepância essencial entre a visão do Ministro Leonel, responsável em última instância pela coordenação do Convice, e a de Eliézer Rizzo sobre o destino atribuído ao documento em questão: para o primeiro, o divórcio entre aquilo que foi produzido 
e a intenção do Presidente era tão flagrante que teria obrigado os seus autores a desistir de apresentá-lo (o próprio general teria se recusado a mostrar o documento a FHC); para o último, o documento teria sido apresentado ao Comandante-emChefe e por ele descartado. ${ }^{27}$ Independentemente dessa divergência, o essencial é notar que o teor do referido documento não obteve acolhida no âmbito do executivo.

\section{A retomada do ímpeto reformador: a criação da Creden e a formulação da PDN}

Até o primeiro semestre de 1996, o processo de criação do MD encontravase atolado no pântano das resistências corporativas. Assim, embora não representasse novidade o fato de haver divergências de entendimento entre as forças singulares quanto aos seus respectivos papéis institucionais, um episódio específico teve peso decisivo na aceleração das mudanças em curso no setor: a querela entre a Marinha e a Aeronáutica em torno da aviação naval embarcada. Não há dúvida de que essa se constituiu em importante elemento para a decisão presidencial de determinar a criação da Câmara de Relações Exteriores e Defesa Nacional (Creden) no âmbito do Conselho de Governo - efetivada em 06 de maio de 1996 pelo Decreto n $1895 .{ }^{28}$ Calcada no modelo de Câmaras Setoriais adotado pela gestão FHC, entre as atribuições da Creden constavam a formulação de políticas, o estabelecimento de diretrizes, a aprovação e o acompanhamento de programas governamentais nas seguintes áreas: cooperação internacional em assuntos de segurança e defesa, integração fronteiriça, populações indígenas e direitos humanos, operações de paz, narcotráfico e outros delitos internacionais, imigração e atividades de inteligência. ${ }^{29}$ De acordo com seu decreto de criação, eram membros da mencionada Câmara: os Ministros das Relações Exteriores, Justiça, Marinha, Exército, Aeronáutica, Emfa, Casa Civil, Casa Militar e da SAE - cabendo ao Ministro-Chefe da Casa Militar atuar como secretário da Creden. Vê-se que o escopo de atuação dessa última é bastante amplo e que a questão dos delitos transnacionais aparece como uma de suas responsabilidades. Interpretação possível a esse respeito é a de que a iniciativa norte-americana de reformulação do conceito de segurança hemisférica, tendo como elemento impulsionador a $1^{\text {a }}$ Reunião Ministerial de Defesa das Américas, em outubro de 1995, somada à realização, em seqüência, pelos Estados Unidos e alguns países andinos, de duas grandes operações conjuntas de combate ao narcotráfico (Green Clover e Laser Strike) na fronteira norte do Brasil, tenham chamado a atenção do governo para a sensibilidade desse tema. ${ }^{30}$ Seriam, portanto, fatores a contribuir incrementalmente para a decisão de criar a Creden.

Não existe, porém, consenso entre os envolvidos no processo sobre o grau de relevância das fricções entre Marinha e Aeronáutica para a iniciativa do Presidente. Embora todos admitam a importância do evento, os então Ministros 
da Marinha e do Emfa consideram que a celeuma em torno da aviação de asa fixa embarcada não teria sido a causa eficiente da decisão presidencial, mas apenas um elemento adicional a contribuir de maneira progressiva para essa última. O ex-Ministro da Marinha afirmará, inclusive, que teria sido ele um dos maiores defensores da idéia da Creden, por acreditar que o Brasil não poderia furtar-se a ter um locus onde fosse possível debater conjuntamente os temas relacionados à defesa nacional. Os críticos da atuação do Almirante Mauro César afirmam, em outro sentido, que o apoio da Marinha à constituição da Creden - que reunia ministérios civis como o Itamaraty, Justiça, Casa Civil e SAE - derivava de uma estratégia para diluir a desvantagem política que essa arma tinha em função do estreitamento das relações entre Exército e Aeronáutica. ${ }^{31}$

A aproximação acima aludida teria se intensificado por causa da mencionada disputa de bastidores em torno da aviação naval. Quanto a esse tema, vêm de longa data as divergências entre as duas forças singulares em questão. Em 1965, depois de uma intensa batalha interburocrática, o Ministério da Aeronáutica (Maer) convenceu o Presidente Castelo Branco a proibir a operação, pela Marinha, de aviões de asa fixa em navio-aeródromo. A essa arma era somente permitido pilotar helicópteros. Dessa forma, cabia ao Maer a operação dos aviões de patrulha nucleados no Minas Gerais. No final do governo Itamar Franco, baseada na concepção de que os meios de superfície da esquadra precisariam de cobertura aérea para atuar afastados do litoral brasileiro (e de que essa não era nem poderia ser provida pela Força Aérea Brasileira (FAB) a curto prazo), a Marinha começou a treinar pilotos na Argentina e no Uruguai - antes mesmo de adquirir os aviões pretendidos para essa tarefa. ${ }^{32}$ A Marinha estava convencida da necessidade de possuir uma "esquadra equilibrada”, o que significava deter a capacidade de desempenhar autonomamente todo o espectro de modalidades de combate atinentes a uma força naval. ${ }^{33}$ Essa intenção esbarrava, contudo, na inexistência de vetores que pudessem prover a cobertura aérea dos navios em alto-mar. A solução contemplada para sanar a carência em tela seria a compra de aviões habilitados a operar a partir do navio-aeródromo Minas Gerais. Diante desse rationale, a posse dos meios materiais capazes de suprir essa lacuna passaria a ser a prioridade número um da Marinha - ainda que em detrimento do projeto de construção do submarino nuclear. Argumento contrário a esse, por sua vez, ressaltava o fato de que os obsoletos aviões de ataque que poderiam ser adquiridos, de qualquer forma, não seriam capazes de fornecer cobertura aérea para a esquadra em alto-mar. Isso, pois dificilmente teriam condições mínimas de operacionalidade em vista da ausência de suporte logístico adequado (contemplava-se adquirir o super etendard francês ou o A-4 Skyhawk americano). Além do mais, a aquisição traria como conseqüência a drenagem de recursos escassos que poderiam ser investidos em projetos até então considerados prioritários como o do submarino de propulsão nuclear. 
Apesar das ponderações dos críticos, desde que assumiu o cargo, em 1995, o Ministro Mauro César empreenderá uma intensa campanha para derrubar a proibição de operação, pela Marinha, de aviões de asa fixa em navio-aeródromo, ${ }^{34}$ o que se chocava com a percepção da Aeronáutica de que somente ela poderia fazê-lo. Embora tenha havido conversas entre marinheiros e aviadores sobre o assunto, não se chegou a uma conclusão definitiva. O então Ministro da Aeronáutica, Lélio Lôbo, salientava que a prioridade de sua força era o reforço da capacidade de manutenção da soberania sobre o espaço aéreo nacional. Nessa linha, a Força Aérea demonstrou não considerar prioritário o investimento na aviação naval. ${ }^{35}$ A despeito disso, além de atentar contra a doutrina do poder aeroespacial unificado - defendida por muitos dentro da força aérea, o intento da Marinha soava como um acinte diante das dificuldades enfrentadas pela FAB. ${ }^{36}$ Essa passava por um dos piores momentos de sua história e se debatia, entre outros problemas, com o penoso processo de revitalização da aviação de caça. ${ }^{37}$ Alguns analistas chegam a sustentar a tese de que a realidade vivida pelo Ministério da Aeronáutica (Maer) naquele momento decorreria do fato de que esse nunca foi uma burocracia militar propriamente. O Maer seria, antes, uma mistura de agência regulatória do setor aeronáutico (Departamento de Aviação Civil - DAC), entidade de fomento à pesquisa tecnológica (Departamento de Pesquisa e Desenvolvimento - Deped) e força aérea (FAB). De acordo com essa linha de raciocínio, o Maer seria apenas "um terço" militar. ${ }^{38}$ A multiplicidade de missões e demandas decorrentes desse perfil teria levado ao colapso da capacidade operacional da FAB em um contexto orçamentário declinante. Essa situação foi responsável por agudizar a sensibilidade corporativa da força no tocante à problemática da aviação naval.

Ao tratar do tema, o Ministro Lélio Lôbo indica claramente a posição de sua arma e confirma a importância da querela para a aceleração do ímpeto reformista de FHC:

Sempre tivemos em mente a necessidade de apoio aéreo para a Marinha. Mas há um enfoque um pouco diferente entre a Aeronáutica e a Marinha. Enfoque esse que, como disse ao Presidente, precisava ser equacionado através de orientação de nível superior. A Marinha tinha um planejamento bélico que não nos parecia afinado com a política de defesa nacional. Aliás, cada força tinha sua própria "política de defesa nacional”, e isso não era bom. Foi em decorrência disso que começou o trabalho que culminou, em 1996, com a aprovação da Política de Defesa Nacional pelo Presidente da República. Foi uma tentativa de colocar uma certa base comum no processo. ${ }^{39}$

Essa afirmativa evidencia as divergências interforças e expõe de maneira cabal a ausência de direção política superior capaz de orientar o preparo militar em sentido harmônico. A admissão explícita da existência de várias políticas de defesa por uma alta autoridade castrense não poderia ser mais reveladora. 
Diante da declaração do ex-Ministro da Aeronáutica, reforça-se a tese de que a disputa envolvendo a aviação naval embarcada em porta-aviões teve caráter instrumental para a criação da Creden. Como já mencionado anteriormente, também contribuiu para tal a percepção de que era preciso constituir um foro permanente de coordenação interministerial na área de defesa e assuntos conexos (especialmente aqueles relacionados aos chamados delitos transnacionais, aí incluído o narcotráfico). Nesse sentido, FHC já vinha realizando reuniões informais com diplomatas e militares para a discussão de temas comuns a ambos, desde o início de seu mandato. ${ }^{40} \mathrm{~A}$ instituição da Creden sinalizou o aumento das preocupações de FHC com a falta de articulação prevalecente no setor. Assim, se, por um lado, as sérias divergências existentes entre Marinha e Aeronáutica foram relevantes para o estabelecimento, pelo governo, de um locus de coordenação institucionalizado, por outro, não resta dúvida de que esse episódio teve papel fundamental para a decisão do Presidente de determinar a formulação da Política de Defesa Nacional (PDN).

A PDN surge não somente como resposta ao desconforto do supremo mandatário em relação às dissensões existentes entre os ministros militares, e as decorrentes pressões de parte a parte com o fito de convencê-lo sobre quem estava com a razão, mas, sobretudo, pela insatisfação de FHC com a forma de condução do assunto imprimida pelo Ministro da Marinha. A avaliação de um observador privilegiado do processo é a de que esse último tentava, em última análise, apresentar ao Presidente um fait accompli - versão negada veementemente pelo Almirante Mauro César. ${ }^{41}$ Ao perceber o que acontecia, FHC teve a convicção de que aquele episódio era a representação definitiva da necessidade de elaboração de um documento público que proporcionasse um quadro de referências comum às forças singulares. Nessa mesma direção, embora muito pouco lembrado, um outro episódio pode ter contribuído para a consolidação da idéia de convocar a Creden e determinar a elaboração da PDN. Em meados de 1996, o Ministério da Aeronáutica fez um pedido oficial de informações às empresas norte-americanas Lockheed Martin e Boeing sobre os caças F-16 e F-18. A FAB já vinha acalentando há muito o sonho de renovar sua envelhecida frota desse tipo de aviões. Solicitou as informações às empresas, contudo, sem nada informar ao Planalto e ao Itamaraty. Nos bastidores, houve suspeitas de que a Força Aérea teria sido induzida a agir assim para que lobbistas de Washington obtivessem argumentos mais sólidos para pressionar as autoridades do governo norte-americano a liberar a venda de armamentos sofisticados à América Latina - até então proibida pela legislação daquele país. Ao chegar aos ouvidos do Presidente, a atitude do Ministério da Aeronáutica causou irritação. Em vista do que precede, ao convocar a segunda reunião da Creden, em 06 de setembro de 1996, FHC instruiu os membros da Câmara a iniciarem os trabalhos para a formulação de uma política de defesa nacional. ${ }^{42}$ 
Na linha da diretiva presidencial, formou-se um comitê com representantes dos membros natos da Creden - em nível de secretários-executivos (ministérios civis) e de chefes de estado-maior (ministérios militares). Naquela ocasião, a Marinha sugeriu que o documento preparado pela SAE, ainda na gestão Flores, fosse tomado como referência inicial para as discussões - note-se que o "Bases para uma Política de Defesa” tinha como características essenciais a generalidade e a influência da nomenclatura esguiana. A partir de então, o Secretário de Assuntos Estratégicos, Ronaldo Sardenberg, desempenhará papel central. Respeitado Embaixador, com longo histórico de interesse pela área de estudos estratégicos, Sardenberg possuía bom trânsito com o Presidente. Em decorrência de sua posição institucional e da qualificação para o trato das questões de defesa, passará a ser um dos principais interlocutores civis de FHC para assuntos militares. Esse fato ensejará a elaboração, por parte do próprio Secretário de Assuntos Estratégicos, de um outro texto que viria a subsidiar os trabalhos do comitê designado pela Creden, intitulado "Apontamentos Tentativos para uma Concepção Estratégica e Política de Defesa Nacional”. Nesse texto, o mencionado Embaixador ressaltará a necessidade de que as Forças Armadas ofereçam respaldo à ação diplomática, bem como que se proceda a um monitoramento conjunto do quadro estratégico internacional. Os "Apontamentos" introduzem, ainda, a idéia de "defesa sustentável”, que visava compatibilizar o aparato militar brasileiro aos recursos disponíveis. ${ }^{43}$

Com base no anteriormente exposto, a formulação da PDN beneficiou-se bastante dos aportes oferecidos pela SAE. Essa, ao que tudo indica, esteve fortemente engajada no processo, espelhando a importância atribuída a ele pelo Secretário de Assuntos Estratégicos. As Forças Armadas, por sua vez, aparecem em vários depoimentos como não estando especialmente entusiasmadas pela elaboração da PDN. ${ }^{44}$ A percepção compartilhada por essas últimas era a de que não se deveria inovar: a política de defesa nacional limitar-se-ia 'a sistematização daquilo que cada uma das forças já vinha fazendo. ${ }^{45}$ De acordo com a perspectiva castrense, portanto, a PDN teria o caráter de um somatório de consensos genéricos. O corolário da generalidade seria, logicamente, a produção de um documento que não implicasse qualquer reorientação expressiva das políticas setoriais levadas a cabo pelas forças singulares - não é por acaso que a Marinha publicará, em 1997, as suas "Diretrizes da Política de Defesa: Ações Decorrentes”, que, de forma nada surpreendente, se encaixa como uma luva na PDN. ${ }^{46}$

A idéia da sistematização do que já existia será reforçada pela rapidez com que a PDN foi elaborada: em apenas dois meses, com número não exaustivo de reuniões semanais, foi possível chegar a um texto consensual. ${ }^{47}$ Note-se, no entanto, que o Presidente teria estabelecido prazo de apenas vinte dias úteis para a produção do documento! Nessas condições, seria de todo improvável chegar a uma fórmula que contemplasse qualquer inovação substantiva em relação às 
convicções arraigadas nos meios militar e diplomático - como de fato pode-se constatar por meio de uma análise detida da PDN.

Mesmo tendo em vista a dificuldade de falar em posições unívocas, capazes de produzir consensos abrangentes dentro de burocracias complexas como as Forças Armadas e a Chancelaria, é preciso admitir que diplomatas e militares possuíam visões discrepantes sobre política de defesa. Esquematicamente, à luz do exposto, pode-se traçar duas posições básicas. A primeira, hegemônica no seio do Itamaraty, trata a problemática de defesa como elemento menor da política externa. A diplomacia brasileira do século XX atuou quase sempre de maneira independente do poder militar. Consolidou-se, ao longo do tempo, a vertente de pensamento diplomático de matriz grociana - que privilegia a dimensão da cooperação. ${ }^{48}$ Embora essa constatação pareça insofismável, a matriz realista da política externa nacional nunca foi completamente soterrada, o que explica a contínua percepção (ainda que pouco enfatizada no plano declaratório) de que os fatores tradicionais de poder permanecem relevantes, ainda que de maneira matizada. No caso específico da formulação da PDN, a visão diplomática dominante não correspondia exatamente àquela da liderança do Ministério das Relações Exteriores (MRE). Dado o maior engajamento no processo demonstrado pela SAE, o Itamaraty acabou se compondo com a primeira. Não há evidências, contudo, de que houvesse divergências importantes entre essas instituições. Logo, no bojo dos conceitos fundamentais que embasavam a posição da "burocracia civil de Estado”, encontrava-se o da relação entre democracia, integração regional, desenvolvimento e paz: amplamente reiterada por meio da menção ao papel do Brasil na construção de uma América do Sul livre de conflitos. ${ }^{49}$ Embora não haja qualquer elemento que sustente a tese de que havia consciência da importância de utilização da política de defesa como meio de alavancar a capacidade de projeção de poder do País (com exceção do caso das operações de paz da ONU), não resta dúvida de que a consolidação da democracia no subcontinente e a nova configuração do sistema internacional condicionavam a redação da PDN, no entender dos diplomatas. Tratava-se, a um só tempo, de afirmar o foco externo da política de defesa, assegurar as intenções pacíficas perante os vizinhos e o mundo, demonstrar o engajamento nacional na construção de uma ordem mundial estável e salientar o papel primordial da diplomacia na resolução de diferendos. A tese da vinculação da defesa às ameaças provenientes do plano internacional, contudo, respondia muito mais à necessidade de renovação dos conceitos herdados da guerra fria do que a um projeto de inserção estratégica global que considerasse a relevância do poder militar como instrumento de respaldo da política externa brasileira. ${ }^{50}$

De outro lado, a posição das Forças Armadas encontrava-se plena de nuances. Em poucas ocasiões é possível falar da existência de uma única perspectiva castrense sobre o que quer que seja. As divergências entre as forças 
singulares serão quase tão comuns quanto as convergências. No que tange à visão militar sobre o relacionamento entre política de defesa e política externa, não será diferente. O exemplo mais conspícuo desse fato é representado pelo antagonismo Marinha versus Exército. Enquanto a primeira possui uma concepção mais ambiciosa a respeito do papel a ser desempenhado pelo País no mundo, o último privilegia uma postura modesta em que a idéia de projeção de poder é secundária em relação à "estratégia da presença". ${ }^{51}$ A despeito do que precede, pode-se traçar um painel genérico com alguns pontos que seriam objeto de consenso. Em vista de suas atribuições constitucionais, todas as três forças possuem responsabilidade pela defesa da soberania e da integridade territorial brasileira em face de ameaças externas. Como decorrência lógica, procuram realizar avaliações da conjuntura internacional de modo a obterem os inputs indispensáveis à estruturação de seus respectivos planejamentos estratégicos. Para tanto, mantêm interlocução permanente com o Ministério das Relações Exteriores. Aqui reside o nó górdio da questão. Na ausência de consenso político mínimo que forneça orientação de longo prazo à ação externa, de documentos declaratórios abrangentes sobre defesa e de burocracia efetivamente capaz de exercer a coordenação das diversas instituições que se ocupam da temática em tela, cada ministério militar acaba por interpretar à sua maneira as linhas de orientação existentes. Essas últimas podem ser resumidas basicamente em: preceitos constitucionais, princípios tradicionais de política externa e diretrizes tópicas emanadas do executivo. A generalidade e a superficialidade das mencionadas guidelines conferem ampla latitude de atuação às forças singulares que as interpretam de acordo com suas lentes corporativas específicas: “(...) as concepções de política externa e de defesa externa, elas estão totalmente divorciadas, elas não têm conexão nenhuma."52 Dessa forma, apesar da variedade de leituras do contexto internacional, calcados em premissas realistas, Marinha, Exército e Aeronáutica possuem em comum a certeza de que o poder militar continua sendo elemento fundamental para a projeção do poder nacional no plano externo.

Mesmo diante de uma gama tão estreita de pontos de convergência, é possível afirmar que a principal discrepância entre a visão das Forças Armadas e a do Itamaraty reside na avaliação da importância do instrumento militar como ferramenta política. Se as primeiras, por motivos óbvios, consideram o poder das armas como essencial para a consecução dos interesses nacionais, o segundo encara-o com grande ceticismo no caso do Brasil. ${ }^{53}$ Geraldo Cavagnari, ao tratar do tema, aponta para o que seria uma incongruência da postura dominante no seio da diplomacia:

A política externa brasileira é coerente com o perfil de potência média. Seu objetivo maior é liderar o processo de integração regional, desde que essa liderança implique, apenas, a busca do consenso - sem custos nem riscos. No campo político-estratégico, a diplomacia procura destacar esse perfil como se fosse 
sinônimo de potência pacífica. Por ser o País vulnerável a condicionalidades e constrangimentos, aposta, de certo modo, na desqualificação da força como meio de solução dos conflitos de interesses. Embora reconheça que a capacidade estratégico-militar ainda é significativa na avaliação do poder, para ela nada impede o Brasil de construir um projeto diplomático baseado na sua capacidade de persuasão - "centrado na paz como instrumento das relações internacionais". (...) Ou seja: ela descarta a força militar do jogo estratégico, ao desqualificar a ação militar como substituto eventual da ação diplomática. ${ }^{54}$

Em última análise, a política externa brasileira não considera a política de defesa como um instrumento significativo para a consecução dos interesses nacionais no plano externo - o que restringiria a margem de manobra do País unicamente ao leito diplomático. Esse fato seria responsável por uma certa alienação conceitual entre a política externa e as questões de defesa. Nesse sentido, a reiteração do legado de Rio Branco pelo Itamaraty, como eixo a partir do qual se plasmariam as linhas de força de nossa diplomacia, é incompleta. Ao enfatizar o seu extraordinário trabalho de consolidação das fronteiras nacionais por meios pacíficos, o pensamento diplomático contemporâneo desconsidera o fato de que o patrono do MRE, apesar de ser um estadista moderado e clarividente, tinha nítida noção da importância de que o Brasil contasse com o respaldo de seu braço armado. ${ }^{55}$

Traço comum tanto a diplomatas quanto a militares, no entanto, é o zelo com que procuram resguardar suas respectivas autonomias corporativas. Nessa direção, não há relatos de que houvesse dissensões importantes entre Marinha, Exército e Aeronáutica no que se refere à PDN. Quanto ao papel desempenhado pelo Itamaraty na elaboração do documento, pode-se dizer que esteve muito alinhado à perspectiva da SAE - até mesmo porque essa Secretaria possuía três diplomatas entre os membros do comitê de elaboração da política de defesa. ${ }^{56}$ Os representantes daquela Secretaria e o do Ministério das Relações Exteriores uniram esforços com vistas a convencer os demais participantes do exercício a eliminar do texto os termos tradicionais do linguajar da ESG - ainda muito presentes no vocabulário castrense. ${ }^{57} \mathrm{O}$ interesse da Chancelaria na redação da PDN, contudo, é relativizado pelo Almirante Mauro César: "Para encerrar esse quesito, a sua indagação direta sobre o interesse do Itamaraty na Política de Defesa. Para ser sincero e honesto, como devo ser em um depoimento como esse, não o vi muito elevado em instante algum."58 De outra perspectiva, Edmundo Fujita, diplomata que participou do processo de elaboração do documento como um dos representantes da SAE, em artigo que avalia o significado de sua publicação, oferece algumas pistas sobre o pensamento prevalecente naquela Secretaria. ${ }^{59}$ Havia, ali, duas ordens básicas de preocupações. A primeira, que a política de defesa refletisse a subordinação militar ao poder civil possibilitada pela consolidação 
do regime democrático no País. A segunda, garantir que fosse incorporada a visão diplomática hegemônica sobre as transformações ocorridas no sistema internacional pós-guerra fria - nos níveis global, hemisférico e regional. Na linha do já mencionado anteriormente, a diplomacia caminhava na direção de acoplar o tradicional conceito de dissuasão às grandes linhas da política externa brasileira, explicitando a preeminência dessa última sobre a primeira. Assim, a utilização dos conceitos de dissuasão e autodefesa na PDN - ambos perfeitamente alinhados ao ponto de vista diplomático - suscita uma série de interrogações. A principal delas é a de que estariam calcados em uma avaliação estática e fatalista da inserção do Brasil no sistema de segurança internacional, além de conterem imperfeições conceituais. O pessimismo quanto à posição ocupada pelo País decorre da já sugerida exclusão da força como instrumento político.

Nesse sentido, algumas questões de fundo precisam ser abordadas para que seja possível compreender as várias dimensões do processo de formulação da PDN. De acordo com a definição conceitual adotada pelo autor desse artigo, não seria tecnicamente correto afirmar que o documento apresentado pelo Presidente, em 7 de novembro de 1996, constituiria uma política de defesa. No entender de Domício Proença e Eugênio Diniz, a PDN poderia ser melhor classificada como uma "harmonização de pontos de vista entre diversas agências responsáveis por assuntos externos do país (...)”. ${ }^{60}$ Mesmo que se admita que a iniciativa presidencial tinha por objetivo desdobrar posteriormente a PDN em uma Política Militar e uma Estratégia Militar brasileiras, não é possível considerá-la uma política de defesa. ${ }^{61}$ Ao limitar-se à reiteração de princípios consagrados da atuação diplomática do País, acrescidos de referências pouco específicas ao papel das Forças Armadas nesse contexto, a PDN elide o estabelecimento de diretrizes claras no tocante aos quatro elementos fundamentais de uma política de defesa: as Forças Armadas, a estrutura integrada de comando e planejamento militar, a institucionalidade governamental para a defesa e a articulação entre política declaratória e prática concreta.

A constatação de que a PDN não é uma política de defesa propriamente dita, contudo, não elimina sua centralidade para a reestruturação do arcabouço institucional brasileiro relacionado ao setor militar. No entanto, há que se admitir: para além da generalidade que permite o uso dos termos do documento para a proposição das mesmas políticas setoriais praticadas antes de novembro de 1996 - o que constitui uma evidente perversão do sentido da PDN, restam outras imperfeições que precisam ser apontadas. A mais flagrante é a que diz respeito à confusão entre segurança e defesa: “A falta de firmeza quanto à aplicação dos conceitos de segurança e defesa permeia toda a Política de Defesa Nacional, tendo como resultado a indefinição se ela é uma política de defesa ou de segurança." ${ }^{62}$ Dessa forma, vários trechos do documento fazem referência a temas como os do desenvolvimento econômico, fortalecimento da democracia, redução 
das desigualdades sociais e dos desequilíbrios regionais como relacionados à defesa. De acordo com o arcabouço conceitual aqui adotado, não é correto associar esses últimos à defesa, mas à segurança. Embora o entrelaçamento entre os dois conceitos seja inescapável, parece totalmente impróprio incluir nas "Orientações Estratégicas” da PDN o seguinte: “O escopo de atuação do Estado brasileiro na área de defesa tem como fundamento a obrigação de prover segurança à Nação, tanto em tempo de paz, quanto em tempo de conflito.” 63 Ora, a idéia de segurança tal como expressa no item mencionado é abrangente demais para ter qualquer significado apreensível. Além do mais, essa “orientação estratégica” atribui à defesa um sentido que ela não tem, qual seja o de prover segurança de maneira abstrata e irrestrita. Decorre desse fato a pergunta: a defesa proverá segurança em que setores (militar, societal, econômico, político, ecológico)? Trata-se de segurança interna, externa ou ambas? Assim, mesmo que se suponha, corretamente, a existência de um vínculo necessário entre defesa e segurança e a importância do desenvolvimento, da coesão social e da diminuição dos desequilíbrios para o fortalecimento da capacidade de defesa nacional, ao não fornecer nenhuma orientação nem representar uma estratégia, o item mencionado é detrimental para a coerência da PDN.

Deve-se aludir a outra seção do documento em que há graves imprecisões: a dos “Objetivos”. Ao salientar a necessidade de que sejam explicitadas as prioridades estratégicas do País a partir dos interesses nacionais e dos objetivos básicos da defesa nacional, caberia uma definição precisa desses dois últimos. No entanto, não há qualquer detalhamento do que efetivamente significam. Esse fato, por si só, torna dispensável a existência daquela seção, porquanto calcada em algo que não se sabe o que é. Nesse ponto, há que se constatar que o documento em análise ainda reflete a influência dos conceitos esguianos - até hoje muito presentes na mentalidade do estamento militar. Tanto é assim que, no item 3.2 da seção “Objetivos”, lê-se: “(...) Esse é o sentido da formulação de uma política de defesa nacional, com recursos para implementá-la, que integre as visões estratégicas de cunho social, econômico, militar e diplomático, e que conte com o respaldo da Nação.” Como não identificar as "visões estratégicas de cunho social, econômico, militar e diplomático" com as conhecidas "expressões do poder nacional” tão propaladas pela Escola Superior de Guerra? Ainda na seção em tela, outros itens que precisariam de revisão são os que relacionam como objetivos da defesa nacional a "garantia do estado de direito e das instituições democráticas” e a "preservação da coesão e da unidade da Nação”. ${ }^{64}$ Quanto ao primeiro, não cabe dúvida de que é inapropriado mencionar o papel de uma política de defesa voltada para ameaças externas na garantia do estado de direito e da democracia, tema de caráter essencialmente doméstico. Ademais, não parece haver processos de securitização no plano internacional que apontem para eventuais tentativas de obliteração das instituições brasileiras. Em relação ao segundo, foge ao espírito da PDN, nos 
termos em que foi formulada, a defesa de algo tão genérico quanto a coesão nacional. O que isso quer dizer? Em que termos se daria essa defesa? Estaríamos diante de uma concessão do grupo de trabalho que redigiu o documento ao ideal tão caro às Forças Armadas, em especial ao Exército, da importância da caserna para a integração e a formação da nacionalidade? Ou para o fortalecimento do civismo e do amor à pátria? Caso contrário, como explicar a inserção desse item na PDN?

As imperfeições enumeradas acima não refletem somente a dificuldade dos formuladores da PDN de esconjurar a herança da ESG. Dessa forma, se, por um lado, as mudanças percebidas no Brasil e no mundo determinavam uma revisão profunda do papel dos militares - cujas missões prioritárias passavam a ser de defesa e não mais de segurança interna, por outro, era impossível ignorar a sensibilidade crescente de questões "não-tradicionais" como o narcotráfico e a criminalidade. A PDN não fará menção a qualquer tipo de ameaça estatal ao Brasil, mas citará especificamente: “(...) A ação de bandos armados que atuam em países vizinhos, nos lindes da Amazônia brasileira, e o crime organizado internacional são alguns dos pontos a provocar preocupação." 65 Ocorre que, ao enfatizar genericamente a vinculação do preparo da defesa às ameaças externas e, ao mesmo tempo, singularizar a preocupação com problemas de caráter essencialmente interno (no caso do narcotráfico e da criminalidade, é bem verdade, há uma interface entre os dois planos), o documento acaba por resvalar, na prática, em temas que nada têm a ver com a defesa.

A ambigüidade aludida pode ser parcialmente explicada pelo peso crescente que a crise da segurança pública vem adquirindo no Brasil contemporâneo, em função, sobretudo, dos efeitos deletérios do tráfico de drogas nos grandes centros urbanos. Nesse contexto, a Amazônia adquire transcendência especial. ${ }^{66}$ Essa vasta porção do território nacional tornou-se o principal objeto de tentativas de securitização por parte das Forças Armadas brasileiras. Nela, identificam-se diversos focos de preocupação que, na perspectiva castrense, seriam passíveis de solapar a soberania do País sobre a área: guerrilheiros, narcotraficantes, garimpeiros, ONGs inescrupulosas, grupos econômicos transnacionais, interesse de terceiros Estados sobre as riquezas amazônicas etc. A variedade de possíveis ameaças fornece uma clara dimensão da abrangência das questões envolvidas. Todas, à exceção da hipótese de tomada da região por uma ou várias potências coligadas, possuem caráter não-estatal. Esse fato, contudo, introduz um elemento de incerteza para a preparação castrense. Se a Amazônia passa a ser a prioridade estratégica número um, mas as ameaças mais prováveis são de natureza nãoestatal - quase todas ligadas a problemas de segurança pública para os quais as Forças Armadas não estão habilitadas a lidar, nem sequer do ponto de vista legal - como é possível dar conta dessa situação? Na prática, não há uma resposta acabada para essa pergunta. Ela ajuda a entender, no entanto, porque a PDN 
menciona o tema da ação de bandos armados e do crime internacional, singularizando a necessidade de defesa da Amazônia.

Na última seção do documento, intitulado "Diretrizes”, as deficiências já citadas refletem-se inevitavelmente. Torna-se muito difícil derivar diretrizes de defesa precisas a partir de objetivos nacionais muito genéricos. A conseqüência lógica desse fato é a enumeração de vinte aspirações pouco específicas e de escassa utilidade para a orientação do preparo militar. A diretriz “q”, por exemplo, que sugere o fortalecimento do sistema nacional de transporte, energia e comunicações, apesar de ter óbvias implicações para a capacidade bélica do Brasil, é tema afeto essencialmente à política de infra-estrutura. Outra diretriz, a "s", pode ser classificada como imprópria, uma vez que se ocupa da política científica do País em relação à Antártica. Essa, salvo engano, não tem nenhuma relação claramente identificável com a política de defesa, devendo antes ser objeto de política de ciência e tecnologia.

A despeito do acima exposto e do fato de que foi muito criticada em função da generalidade com que aborda a problemática da defesa, a PDN também possui aspectos positivos e inovadores. Considerando que os principais objetivos de FHC eram os de adequar Marinha, Exército e Aeronáutica a mecanismos de controle vigentes em democracias consolidadas (supremacia do poder civil), além de conferir racionalidade ao sistema de defesa brasileiro a partir do estabelecimento de um quadro de referências comum, o aspecto inovador mais evidente é o da participação de civis no processo de formulação da PDN. Esse fato rompe com o padrão de monopólio militar sobre a elaboração de documentos relacionados à defesa, bem como com o caráter sigiloso até então atribuído a instrumentos semelhantes. Outra característica a ser enfatizada, a despeito das contradições já expostas, é a da determinação explícita de que a PDN tem por base as ameaças provenientes do exterior, vinculando-a de maneira inequívoca às relações exteriores ou, em outras palavras, conectando militares e diplomatas. ${ }^{67}$

A relação informal existente até então entre o Itamaraty e as forças singulares, quase sempre para o tratamento de questões pontuais que dissessem respeito às duas burocracias, foi balizada de maneira abrangente por intermédio da PDN. Pela primeira vez, formulou-se conjuntamente um documento declaratório sobre defesa em que o vínculo institucional entre a diplomacia e as Forças Armadas é claramente articulado a partir de uma base comum de entendimentos. A embasar a redação da PDN, estava a percepção de FHC de que se deveria romper definitivamente com as perspectivas que fundamentaram o preparo militar (especialmente do Exército) no passado, atribuindo prioridade ao papel castrense no respaldo às iniciativas de política externa do País. Não é à toa que o texto da PDN faz inúmeras referências à articulação entre política externa e política de defesa. ${ }^{68}$ Entre elas, talvez a mais significativa seja a que afirma que "a presente política é centrada em uma ativa diplomacia voltada para a paz e em uma postura 
estratégica dissuasória de caráter defensivo (...)”. ${ }^{69}$ Também digno de nota é o fato de que, naquele momento, o Brasil postulava um assento permanente no Conselho de Segurança das Nações Unidas (CSNU), o que condicionava o preparo militar no sentido da participação em missões de paz da ONU. ${ }^{70}$ Acreditava-se que o engajamento nessas missões poderia trazer, como efeito colateral positivo, estímulo à profissionalização das forças e elevação da estatura estratégica nacional. ${ }^{71}$ Ainda nessa linha, aproveitou-se a oportunidade do lançamento da PDN para capitalizar dividendos internacionais, tendo em vista que o documento foi imediatamente entregue aos embaixadores residentes em Brasília, bem como diretamente aos governos com os quais o País mantinha relações diplomáticas.

Coerentemente com a postura histórica adotada pelo Itamaraty e pelas Forças Armadas, a PDN trata com acentuada prudência a possibilidade de participação nacional em alianças militares. Ao contrário da contribuição às missões de paz da ONU, encara-se com grande ceticismo o engajamento brasileiro em alianças desse tipo. $\mathrm{O}$ fundamento dessa posição reside na avaliação de que não seria conveniente ao País limitar sua margem de manobra vinculando-se a arranjos internacionais potencialmente restritivos. A circunstância político-estratégica da América do Sul, caracterizada pela prevalência de relações pacíficas entre os Estados que a compõem, contribuiria adicionalmente para a baixa prioridade atribuída ao tema. Dessa forma, e levando em conta a presença norte-americana no hemisfério, a posição do governo brasileiro privilegia o reconhecimento da existência de uma multiplicidade de ambientes estratégicos nas Américas, o que dificultaria a adoção de soluções genéricas para os problemas de segurança dos países da região. A PDN reflete essas preocupações e, embora saliente a importância de que a política de defesa auxilie os esforços de integração e acercamento com os Estados vizinhos, não menciona a participação nacional em qualquer aliança de caráter militar. Assume-se, portanto, uma postura de self-help em que o Brasil implicitamente admite que sua defesa dependerá, exclusivamente, dele mesmo.

Como já citado anteriormente, embora os termos da PDN apontem para a centralidade da articulação entre política externa e de defesa, há também elementos que dão margem à ambigüidade quanto ao papel a ser exercido pelas Forças Armadas no âmbito doméstico. Tendo em vista que no documento não há menção a missões voltadas para o controle social, combate ao narcotráfico, garantia da lei e da ordem etc., registra-se no plano prático uma discrepância notável entre essa ausência e o número de vezes em que o governo FHC utilizou o Exército para tais fins. ${ }^{72}$ A tensão esquematicamente apontada acima reflete-se claramente em toda sua gestão. A prioridade conferida à vinculação da política de defesa à política externa expressa na PDN, não estando calcada em um abrangente consenso político - uma vez que o documento foi elaborado no âmbito do executivo e somente depois apresentado ao Congresso - e tampouco em um planejamento diplomático 
que incorporasse a utilização do poder militar como ferramenta efetiva, representou muito pouco em termos objetivos. Mesmo a participação em operações de paz da ONU, algo no qual o Itamaraty gostaria de ver as Forças Armadas engajadas, não pôde ser conduzida a contento em vista de sua baixa relevância para o preparo militar tradicional e de seus altos custos de implementação. ${ }^{73}$

Há, portanto, ao longo da presidência FHC, uma clara incongruência resultante da disjunção entre política declaratória e prática concreta. Isso não é surpreendente na medida em que a temática de defesa nunca foi objeto de preocupação prioritária durante a gestão FHC. Assim, exemplo cabal do acima exposto pode ser encontrado na forma como se encaminhou a decisão de criar a Creden e determinar a elaboração da PDN. Salvo melhor juízo, inexistia, até o transbordamento da querela Marinha versus Aeronáutica, qualquer planejamento por parte do Presidente no sentido de estabelecer uma política de defesa que conferisse uma base de entendimentos comum às forças singulares e ao Itamaraty. Ao que tudo indica, a idéia original de constituição do MD não incluía como etapa prévia a produção da PDN. Essa, ao contrário, surge como uma espécie de balizamento a partir do qual seria possível avançar no processo de constituição do Ministério da Defesa, que até então patinava.

Embora, no limite, seja possível atribuir a elaboração da PDN a uma circunstância aleatória, o fato é que os termos tradicionais da equação institucional foram invertidos. Intuitivamente, supõe-se que a elaboração de um documento declaratório sobre defesa, abarcando as três forças singulares, deveria ser encaminhada pela instância governamental responsável pela coordenação das políticas setoriais de cada uma delas. No caso brasileiro, essa instância, para todos os fins, não existia, uma vez que o Emfa não cumpria essa função e o processo de criação do Ministério da Defesa encontrava-se em estágio incipiente. No plano concreto, delineavam-se as grandes linhas de ação no tocante à postura estratégica do País sem que houvesse um órgão ou um colegiado cuja tarefa fosse garantir que as diversas burocracias envolvidas caminhassem no sentido desejado. Sugestivamente, a PDN não faz uma menção sequer ao MD, embora cite a necessidade de integração das Forças Armadas "em seu preparo e emprego, bem como da racionalização das atividades afins."74 Surgia, assim, uma orientação governamental de alto nível para as burocracias direta ou indiretamente responsáveis pela defesa que, na realidade, não poderia ser implementada em vista da inexistência de um locus institucional adequado. Aliás, a implementação do documento só poderia ser levada à frente a partir do momento em que esse fosse desdobrado em uma política e uma estratégia militares. Nessa linha, levandose em conta que a PDN, como documento mais abrangente, representava, ainda que somente no plano formal, mudança em relação ao que existia no passado, tornava-se de fato inócuo o conteúdo da política militar brasileira publicada pelo Emfa na administração Itamar Franco. Para que fosse possível pensar em uma 
implementação efetiva, o primeiro passo seria a reformulação desse último documento à luz da PDN.

A despeito de ter surgido de forma não-planejada, a PDN converteu-se em um passo lógico em direção ao Ministério da Defesa. Se o procedimento ortodoxo seria primeiro unificar Marinha, Exército e Aeronáutica sob o comando do MD e depois elaborar uma política de defesa que fornecesse as linhas de orientação para o preparo castrense, no plano concreto ocorreu o oposto. Inicialmente, formulou-se um documento declaratório que, apesar de suas deficiências, serviu como elemento impulsionador do processo de mudança que até então caminhava lentamente: "Indicamos ainda que esse instrumento (a PDN) reforça a disposição do Presidente em implantar o Ministério da Defesa no próximo ano, Ministério que deverá apropriar-se de uma mentalidade civil no tratamento da Política de Defesa Nacional..."75 Ainda que se considere que a PDN não faz nenhuma alusão ao MD, o importante a reter é a idéia de gradualismo já mencionada em outra parte desse texto. Em face das importantes resistências corporativas à perspectiva de rebaixamento do status dos ministérios militares consubstanciada na criação do MD, a redação do documento sobre política de defesa, centrada na busca de consenso, evitou tocar no assunto. Contudo, ao prever a necessidade de integração com a política externa e de interoperabilidade das forças singulares, a PDN deixou aberta a porta para a justificação técnica e política do Ministério da Defesa. A base comum de entendimentos possibilitada pelo documento converteu-se em passo importante para o avanço do processo reformista empreendido por FHC.

De início, a publicação da PDN cria um momentum favorável ao sinalizar publicamente o empenho do Comandante-em-Chefe em caminhar no sentido da modernização do arcabouço institucional que instruía a ação de governo na área de defesa: movimento claro nessa direção pode ser constatado a partir do resultado do trabalho do Convice, finalizado em data muito próxima à da PDN e que não obteve qualquer ressonância no âmbito do executivo. O documento contribuiu, da mesma forma, como um ensaio do que viria a ser o processo de constituição do MD, no qual as Forças Armadas foram obrigadas a trabalhar em conjunto com membros da burocracia civil, refletindo o enfraquecimento do padrão de autonomia corporativa irrestrita até havia pouco verificado no tratamento desse tipo de questão. Pode-se argumentar, ainda, que a PDN conferiu sentido à Creden, locus de coordenação que permanecia inerte até a determinação presidencial de formular uma política de defesa. Todos esses fatores contribuíram para emprestar relevância ao documento produzido. 


\section{A implementação da PDN? A criação do Ministério da Defesa (MD) e suas implicações para a articulação entre a política externa e a política de defesa}

Deve-se indagar a respeito da plausibilidade de implementação da PDN e da conexão dessa com a criação do MD. Em face de todas as dificuldades conceituais e políticas apontadas na seção anterior, não é possível comprovar que tenha havido uma implementação efetiva da PDN. Ao contrário, essa parece ter sido muito mais uma peça de retórica do que um balizamento concreto para a ação diplomática e militar. Isso torna-se evidente a partir do momento em que se constata que o documento não se traduziu em diretrizes específicas para o preparo castrense e tampouco para o planejamento da política externa brasileira. A PDN serviu, antes, como uma ferramenta política de dupla função: avançar na subordinação da caserna ao poder civil e apontar para a mudança das bases conceituais em que se assentava a preparação militar, vinculando-a à agenda externa. Adicionalmente, contribuiu para impulsionar a criação do MD na medida em que sinalizou a intenção do Presidente de romper com o marasmo burocrático que imperava em meados de 1996. Assim, a existência da PDN, embora esta não cite o MD em momento algum, criou uma demanda no sentido da institucionalização de uma burocracia capaz de dar conseqüência ao seu conteúdo. Logo, a idéia de que a PDN teria se constituído em um passo lógico na direção do Ministério da Defesa sustenta-se plenamente.

\section{Conclusão}

Durante a gestão Cardoso, a prioridade atribuída à inserção competitiva do País na economia internacional foi acompanhada por um baixo perfil no plano político, em que a nota mais significativa foi a adesão a praticamente todos os regimes de não-proliferação de armas de destruição em massa. Note-se que esse curso de ação, justificado com base na idéia de resgate de hipotecas do passado, foi implementado sem a negociação de qualquer contrapartida expressiva. A resultante desse processo revela-se por meio da incorporação e resolução de uma carregada agenda negativa no campo da segurança internacional. Não está claro, contudo, se as ações empreendidas tiveram por base reflexão serena e abrangente sobre as conseqüências de longo prazo do trabalho de limpeza de pauta realizado. Um dos mais evidentes indícios de que a aludida reflexão inexistiu pode ser encontrado na própria ausência de nitidez e nas imperfeições conceituais observadas na Política de Defesa Nacional. Logo, se o documento normativo de alto nível sobre defesa, elaborado por diplomatas e militares, possui incongruências consideráveis, como esperar que a política de enquadramento do Brasil nos regimes de não-proliferação não as tivesse? 
Em relação à PDN, constata-se que essa nasce de uma circunstância aleatória - a disputa entre Marinha e Aeronáutica em torno da aviação naval - e não de um planejamento coerente de construção de um novo arcabouço institucional para o setor. O resultado dessa circunstância expressou-se por meio da produção de um documento que não pode ser classificado como uma política de defesa e que se limita a refletir posições tradicionais da Chancelaria e das Forças Armadas. Como essas posições não estavam lastreadas em diretrizes claras emanadas do poder político - considerando que os princípios genéricos da Constituição são insuficientes para especificar as políticas efetivamente praticadas pelas burocracias pertinentes, a solução encontrada privilegiou a generalidade como forma de garantir a manutenção daquilo que já existia. A PDN não representou, portanto, qualquer constrangimento significativo à continuidade das políticas setoriais pouco articuladas perseguidas por diplomatas e militares. Ao fim e ao cabo, produziu-se uma síntese imperfeita entre a política externa e a política de defesa.

A falta de um elemento integrador das visões do Itamaraty, da Marinha, do Exército e da Aeronáutica permanece depois da publicação da PDN. Esse elemento integrador expressar-se-ia, idealmente, por meio da existência de um consenso político abrangente capaz de produzir diretrizes de longo prazo precisas, formais ou informais, sobre o papel a ser desempenhado pelo Brasil no mundo. A partir daí, seria possível definir as políticas externa e de defesa mais adequadas para a obtenção dos objetivos almejados, bem como os mecanismos conjuntos de coordenação e avaliação apropriados. Ocorre que o consenso necessário ao estabelecimento de um projeto nacional não existia e talvez não venha a existir em um País complexo e desigual como o Brasil. Na sua ausência, caberia ao supremo mandatário inferi-lo e implementá-lo durante o período de seu mandato. Isso, contudo, não ocorreu no caso de FHC. Embora tenha dado grande atenção à área externa, o setor de defesa pôde ser contemplado apenas de maneira limitada. Ademais, a cautela com que foi abordada a reformulação do aparato institucional relacionado ao campo militar deu margem a que dinâmicas corporativas inerciais fossem mantidas. Muitas das contradições mais evidentes encontradas na PDN decorrem da manutenção, com pequenas variações de vocabulário, de concepções antigas e por vezes incompatíveis existentes nos âmbitos diplomático e castrense. A PDN, a despeito do que precede, foi um elemento importante, mas não essencial, para o processo de implementação do MD. No plano empírico, representou um passo lógico no caminho da criação do novo ministério. Apesar disso, esse só se concretizou a partir do momento em que o processo de formulação foi ampliado para a esfera civil, saindo do controle militar.

Constata-se, no entanto, que a PDN e o MD não foram capazes de intensificar a articulação entre a política externa e a política de defesa. Como já mencionado nesse artigo, se, ao longo de quase todo o século XX, a diplomacia brasileira prescindiu do braço armado como elemento de respaldo da ação externa, 
seria surpreendente que uma constante tão arraigada fosse modificada pela simples publicação de um documento declaratório sobre defesa e pela implantação de uma nova estrutura administrativa responsável pelo tratamento unificado da temática militar. Da mesma forma, se as forças singulares atuaram durante muitas décadas com total autonomia em relação às políticas setoriais praticadas pelas demais forças e pelo Itamaraty, não seria em um par de anos que haveria uma modificação significativa desse quadro. Mudanças concretas só poderiam ocorrer na presença de um firme comprometimento do executivo e do legislativo (em última análise da sociedade) no sentido de aprofundar as reformas em curso. Ainda que se considere que havia algum interesse pelo tema no âmbito do executivo, derivado basicamente da intenção presidencial de enquadrar a caserna em uma moldura institucional disseminada nas democracias do Ocidente, o mesmo não pode ser dito do legislativo - que manteve quase inalterado seu sólido desinteresse pelos assuntos relacionados à defesa. Esse fato, somado às naturais resistências corporativas, conduziu o País à consolidação de uma reforma a la Lampedusa. Assim, a política de defesa efetivamente praticada permanece implícita, não-integrada e articulada apenas em nível superficial com a política externa.

No plano da realidade, as relações entre as Forças Armadas e o Itamaraty, agora mediadas pelo MD, mantêm-se desvinculadas no que concerne à coordenação de esforços de longo prazo. Inexiste qualquer mecanismo operacional - ainda que a Creden, ou o próprio Conselho de Defesa Nacional (CDN), pudesse representar o foro adequado - de formulação conjunta de políticas, inclusive das de caráter contingencial. Nessa linha, as esporádicas conversas informais entre diplomatas e militares, que se processam em base ad hoc, são insuficientes como sucedâneos de uma coordenação organicamente organizada. Aspecto notável nesse sentido é a falta de integração no que se refere ao planejamento de ações de contingência no caso de ameaça à integridade do patrimônio brasileiro localizado na área de fronteira. Até onde vai a informação disponível, cada força singular possui um plano específico para esse tipo de situação que não leva em conta os planos existentes nas demais, sem falar na ausência de procedimentos de consulta à Chancelaria. ${ }^{76}$

De acordo com o que se procurou demonstrar ao longo desse artigo, as percepções de ameaça no Brasil também representam fatores críticos para que se torne difícil a alteração do quadro atual de baixa articulação sistêmica entre as políticas externa e de defesa. À medida que a crise da segurança pública se aprofunda e que não há processos de securitização de ameaças externas clássicas, cada vez mais pressão é exercida por segmentos da sociedade para que as Forças Armadas se engajem no combate ao crime organizado. Esse estado de coisas, caso não se reverta, pode ser desastroso para o País. Isso, pois a experiência de outras nações alerta para o fato de que o engajamento das Forças Armadas no 
combate ao crime possui três conseqüências negativas fundamentais: debilita a capacidade combatente em função da incompatibilidade entre as demandas profissionais da atividade policial e da preparação para a guerra, expõe as instituições castrenses à corrupção e possibilita o comprometimento da democracia ao franquear à corporação armada de "última instância" a prerrogativa de intrusão em assuntos que possuem óbvias implicações políticas como os relacionados à segurança pública.

Somente a partir de um trabalho intenso e continuado com vistas a promover a difusão de conhecimento sobre as questões concernentes à diplomacia e à defesa, será factível modificar o atual estado de coisas. Trata-se, em última análise, de romper a lógica circular perversa existente, caracterizada por: desinteresse/ desconhecimento/ baixa prioridade política/ baixos orçamentos/ inexistência de controles externos efetivos/autonomia disfuncional/ irrelevância/ desinteresse/ desconhecimento... Finalmente, partindo do que foi dito nesse estudo, torna-se inadiável voltar a pensar a política externa de maneira integral. A reflexão a respeito da instrumentalidade dos meios de coerção para a sobrevivência e o fortalecimento da posição de um Estado no sistema internacional não pode, em hipótese alguma, ser considerada um tema menor. A experiência histórica demonstra que não se forja uma grande nação sem que essa esteja respaldada por poder militar compatível. No caso brasileiro, estamos muito longe de romper o limiar que nos separa dos países desenvolvidos. No entanto, é difícil imaginar como esse limiar possa ser um dia rompido sem que o País conte com um aparato de defesa condizente com a posição almejada. Todos os caminhos apontam, portanto, para a necessidade de reconsiderar urgentemente a interface entre a política externa e a política de defesa nacionais. Quem sabe refletir sobre o assunto não seja um bom começo?

Outubro de 2003

\section{Notas}

1 Ver BUZAN, Barry; WEAVER, Ole; DE WILDE, Jaap. Security: a new framework for analysis. Boulder: Lynne Rienner Publishers, 1998.

2 Ver DANESE, Sérgio. Diplomacia presidencial: história e crítica. Rio de Janeiro: Topbooks, 1999.

3 CERVO, Amado. Relações Internacionais do Brasil. In: CERVO, Amado (Org.). O desafio internacional: a política exterior do Brasil de 1930 a nossos dias. Brasília: Editora Universidade de Brasília, 1994. p. 9-58. HELD, David. Democracy and the global order: from the modern State to cosmopolitan governance. Stanford: Stanford University Press, 1995. p. 92.

5 FONSECA JR., Gelson. Anotações sobre as condições do sistema internacional no limiar do século XXI: a distribuição dos pólos de poder e a inserção internacional do Brasil. In: DUPAS, Gilberto; VIGEVANI, Tullo (Orgs.). O Brasil e as novas dimensões da segurança internacional. São Paulo: Editora Alfa-Omega, 1999. p. 31. 
LAMPREIA, Luiz Felipe Palmeira. Diplomacia brasileira: palavras, contextos e razões. Rio de Janeiro: Lacerda Editores, 1999. p. 18-19.

7 FERREIRA, Oliveiros S. A crise da política externa: autonomia ou subordinação? Rio de Janeiro: Editora Revan, 2001. p. 17-18.

8 Ver HELD, David et al. Global transformations: politics, economics and culture. Stanford: Stanford University Press, 1999. p. 87-148.

9 Ver GOLDEIER, J.M.; McFAIL, M. A tale of two worlds: core and periphery in the postCold War era. International Organization. N. 46: 2, p. 467-491. 1992.

10 Ver HURRELL, Andrew. An emerging security community in South America? In: ADLER, Emanuel; BARNETT, Michael (Orgs.). Security Communities. Cambridge: Cambridge University Press, 1998. p. 228-264. KACOWICZ, Arie M. Zones of peace in the Third World: South America and West Africa in comparative perspective. New York: State University of New York Press, 1998. HOLSTI, Kalevi J. The State, war, and the State of war. Cambridge: Cambridge University Press, 1996.

BRIGAGÃO, Clóvis; PROENÇA JR., Domício. Concertação múltipla: inserção internacional de segurança do Brasil. Rio de Janeiro: Livraria Francisco Alves Editora, 2002. p. 54.

MINISTÉRIO DA DEFESA. História do MD. 2001. Disponível em: <http:// www.defesa.gov.br/historia/historia.htm>. Acesso em: 03 out. 2002.

13 Ver OLIVEIRA, Eliézer Rizzo de. O Ministério da defesa: a implantação da autoridade. In: Research and education in defense and security studies, Brasília: 1, 2002. p. 6-7. Paper apresentado no painel sobre estudos de casos sobre ministérios da defesa. Idem. p. 3-4.

LEONEL, Benedito Onofre Bezerra. Brasília, jul. 2002. Entrevista concedida ao autor. OLIVEIRA, Eliézer Rizzo de. Op. cit., p. 4.

17 LEONEL, Benedito Onofre Bezerra. Op. cit.

18 Idem.

19 CAMPOS, Íris Walquiria. Defesa Nacional. In: LAMOUNIER, Bolívar; FIGUEIREDO, Rubens (Orgs.). A era FHC, um balanço. São Paulo: Cultura Editores Associados, 2002. p. 465.

OLIVEIRA, Eliézer Rizzo de. Op. cit., p. 3.

21 HUNTER, Wendy. Assessing civil-military relations in postauthoritarian Brazil. In: KINGSTONE, Peter R.; POWER, Timothy J. (Orgs.). Democratic Brazil: actors, institutions and processes. Pittsburgh: University of Pittsburgh Press, 2000. p. 103 MINISTÉRIO DO PLANEJAMENTO E ORÇAMENTO. Plano Plurianual 1996-1999: mensagem ao Congresso Nacional. Brasília: Secretaria de Planejamento e Avaliação/MPO, 1996. p. 95.

LEONEL, Benedito Onofre Bezerra. Op. cit. Idem.

Estudo nº 01/Convice-C. apud Eliézer Rizzo de Oliveira. O Ministério da Defesa: a implantação da autoridade. op. cit. p.5.

26 LEONEL, Benedito Onofre Bezerra. Op. cit.

27 OLIVEIRA, Eliézer Rizzo de. Op. cit., p. 11-12.

28 COSTA, José Luiz Machado e. Brasília, out. de 2001. Entrevista concedida ao autor.

29 Ver BRASIL. Decreto no 1895 , de 06 de maio de 1996.

30 PINTO, Paulo Cordeiro de Andrade. Diplomacia e política de defesa. Brasília: Instituto Rio Branco, 2000. p. 148.

31 Sobre a estratégia da Marinha e a aproximação do Exército com a Aeronáutica, ver D’ARAUJO, Maria Celina; CASTRO, Celso (Orgs.). Militares e política na Nova República. Rio de Janeiro: Editora FGV, 2001. p. 38-40.

32 PEREIRA, Mauro César Rodrigues. Entrevista. In: D’ARAUJO, Maria Celina; CASTRO, 
Celso (Orgs.). Op. cit., p. 284.

CAMPOS, Íris Walquiria. Op. cit., p. 479.

O intento do Ministro Mauro César seria posteriormente concretizado por meio do Decreto $n^{0}$ 2.538, de 8 de abril de 1998.

LÔBO, Lélio Viana. Entrevista. In: D’ARAUJO, Maria Celina, CASTRO, Celso (Orgs.). Op. cit., p. 242.

Idem.

Havia dois projetos em curso. Um, o chamado projeto FX que visava à substituição dos envelhecidos e obsoletos caças mirage III por volta de 2005. Outro, mais premente, e que se arrastava havia muito tempo, tratava da modernização dos caças F-5 - também obsoletos e totalmente incapazes, assim como os mirage, de atuar em um teatro de operações moderno. Esse último projeto, segundo fontes jornalísticas, teria se iniciado em 1986!

Ver BRIGAGÃO, Clóvis; PROENÇA JR., Domício. Op. cit., p. 82.

LÔBO, Lélio Viana. Op. cit., p. 241.

PINTO, Paulo Cordeiro de Andrade. Op. cit., p. 148.

COSTA, José Luiz Machado e. Op. cit.

PINTO, Paulo Cordeiro de Andrade. Op. cit., p. 150.

Idem. p. 151. Note-se que esse conceito, ainda que não propriamente especificado, aparecerá no texto da PDN.

COSTA, José Luiz Machado e. Op. cit.

LEONEL, Benedito Onofre Bezerra. Op. cit.

DIRETRIZES DA POLÍTICA DE DEFESA: AÇÕES DECORRENTES. 1997. Disponível em: <http://www.infomarmb.hpg.ig.com.br/diretrizes_do_pdn.htm> Acesso em: 05 dez. 2001. FUJITA, Edmundo Sussumo. Brasília, dez. de 2001.Entrevista concedida ao autor.

LAFER, Celso. A identidade internacional do Brasil e a política externa brasileira: passado, presente e futuro. São Paulo: Perspectiva, 2001. p. 47.

DOCUMENTO SOBRE POLÍTICA DE DEFESA NACIONAL. Parcerias Estratégicas. O Quadro Internacional. Item 2.10. Vol. 1, n 2, p. 10, dez. 1996.

Sobre a relação poder militar-política externa, ver CAVAGNARI, Geraldo Lesbat. Introdução Crítica a Atual Política de Defesa. Carta Internacional, ano IX, nº 96, fev. 2001. p. 11-12.

Para um depoimento esclarecedor sobre o pensamento da liderança do Exército Brasileiro sobre as “estratégias" a serem perseguidas, ver LUCENA, Zenildo Zoroastro de. Entrevista. In: D’ARAUJO, Maria Celina, CASTRO, Celso (Orgs.). Op. cit. p.203-225. Para uma crítica aguda das incoerências resultantes da coexistência das “estratégias” da presença e da dissuasão, ver BRIGAGÃO, Clóvis; PROENÇA JR., Domício. Op. cit., p. 74-81.

FLORES, Mário César. Rio de Janeiro, dez. de 2001. Entrevista concedida ao autor. CAVAGNARI, Geraldo Lesbat. Op. cit., p. 11.

Idem.

PARANHOS, José Maria da Silva Apud RICUPERO, Rubens. Barão do Rio Branco: uma biografia fotográfica. Brasília: Fundação Alexandre de Gusmão, 1995. p. 114-115.

Eram eles o Ministro Edmundo Fujita, Subsecretário de Análises e Avaliação, o Conselheiro Paulo Cordeiro, Diretor do Centro de Estudos Estratégicos, e o Conselheiro José Luiz Machado e Costa, cedido pela Presidência da República à SAE especificamente para o exercício de elaboração da PDN.

O Itamaraty era representado pelo Secretário de Planejamento Diplomático, embaixador Lúcio Amorim, a Marinha pelo almirante Davena, o Exército pelo general Câmara Sena, a Aeronáutica pelo brigadeiro Candiotti, o Emfa pelo general Ariel e a Casa Militar por vários coronéis que se alternavam.

PEREIRA, Mauro César. Entrevista, por escrito, concedida ao autor. Londres, jul. de 2002. Ver FUJITA, Edmundo S. Uma Política de Defesa Sustentável para o Brasil. Parcerias 
Estratégicas. Vol. 1, nº 5, set. 1998. Disponível em: <http://www.mct.gov.br/CEE/revista/ Parcerias5/polidesu.htm>. Acesso em: 05 dez. 2001.

60

PROENÇA JR., Domício; DINIZ, Eugênio. Política de defesa no Brasil: uma análise crítica. Brasília: Editora Universidade de Brasília, 1998. p. 18.

CARDOSO, Fernando Henrique. Discurso proferido em 07 de novembro de 1996 quando do lançamento da Política de Defesa Nacional. Parcerias Estratégicas. Vol. 1, nº 2, dez. 1996. p. 18. Para uma definição conceitual sobre o que seria Política Militar e Estratégia Militar, ver LONGO, Airton Ronaldo. Planejamento Estratégico da Marinha. Revista Marítima Brasileira. Vol. 122, nº 04/06, abr./jun. 2002. p. 29.

GUSMÃO, Luiz Guilherme Sá de. Política de Defesa Nacional: uma análise crítica e comparativa. Revista Marítima Brasileira. Vol. 122, nº 04/06, abr./jun. 2002. p. 202.

DOCUMENTO SOBRE POLÍTICA DE DEFESA NACIONAL. Parcerias Estratégicas. Orientação Estratégica. Item 4.1. Op. cit., p. 11.

Idem. Itens 3.3B e 3.3C. p. 11.

Ibidem. Item 2.12. p.10..

MIYAMOTO, Shiguenoli. A Política de Defesa Brasileira e a Segurança Regional. Contexto Internacional. Vol. 22, $\mathrm{n}^{\circ}$ 2, jul. 2000. p.465-466.

DOCUMENTO SOBRE POLÍTICA DE DEFESA NACIONAL. Parcerias Estratégicas. Introdução, Itens 1.3 e 1.4. Op. cit., p.7.

Idem. Itens 1.2, 1.3, 1.4, 1.6, 2.5, 2.8, 2.9, 2.11, 2.13, 3.2, 3.3E, 3.3F, 3.3G, 4.2, 4.3, 5.1A, 5.1B, 5.1C, 5.1D, 5.1E, 5.1F, 5.1G, 5.1H. p.7-15.

Ibidem. Item 4.2. p. 11.

HUNTER, Wendy. Op. cit. p. 116.

FONTOURA, Paulo Tarisse da. Brasília, jun. de 2002. Entrevista concedida ao autor.

OLIVEIRA, Eliézer Rizzo de. Política de Defesa Nacional e relações civis-militares no governo do Presidente Fernando Henrique Cardoso. Caderno Premissas. № 17-18, maio de 1998. p. 61-68.

73 Ver ALSINA JR., João Paulo Soares. Relações civis-militares e política de defesa no Brasil e na Argentina pós-transição. Brasília: mimeo, dez. 2001. 26 p.

DOCUMENTO SOBRE POLÍTICA DE DEFESA NACIONAL. Op. cit., p.13.

OLIVEIRA, Eliézer Rizzo de. Op. cit., p. 67.

FLORES, Mário César. Op. cit.

\section{Resumo}

Esse artigo tem por objetivo gerar hipóteses sobre a articulação entre política externa e política de defesa na gestão Cardoso. Partiu-se de estudo de caso sobre a formulação da Política de Defesa Nacional (PDN) e as conseqüências dessa para a institucionalização do Ministério da Defesa (MD). Constatou-se a baixa prioridade atribuída pela diplomacia ao poder militar como ferramenta de política externa. Finalmente, explicitou-se a inexistência de mecanismos efetivos de articulação. 
Abstract

This article has the objective of producing hypotheses on the articulation between foreign and defense policies during President's Cardoso administration. Initially, a case study on the formulation of the National Defense Policy Document (PDN) and its consequences to the institutionalization of the Defense Ministry (MD) was conducted. The low priority Brazilian diplomacy attributes to military power as a foreign policy tool was established. Finally, the lack of effective articulation mechanisms between foreign and defense policies was stressed.

Palavras-chave: Política externa; Política de defesa; Articulação; Gestão Cardoso. Key words: Foreign Policy; Defense Policy; Articulation; Cardoso administration. 